УДК 821.163.41.09:929 Јанковић, Милица https://doi.org/10.18485/godisnjak.2016.11.5

Славица О. Гароња Радованац* Филолошко-уметнички факултет Крагујевац
Оригинални научни рад Примљен: 05. 10. 2016. Прихваћен: 20. 10. 2016.

\title{
ПРИПОВЕДНИ ОПУС МИЛИЦЕ ЈАНКОВИЋ - ЈЕДНА МОГУЋА АУТОБИОГРАФИЈА
}

Јер литература је уметност која скупља лепоте истине и маште, она је есениија лепоте живота. Она сачињава идеалну вредност жсивота, она је његов драги камен.

Милица Јанковић („Час стварања”, 1920)

У раду се разматрају збирке приповедака Милице Јанковић (18811939), објављиване у међуратном периоду, укупно њих седам (сем њене прве збирке Исповести (1913), којом је ушла у Скерлићеву Историју новије српске књижевности, и која је до сада углавном и једина била у фокусу интересовања књижевне науке). Збирке приповедака, настајале од 1919. до 1937. на неки начин, остале су потпуно скрајнуте у истраживању њеног приповедног опуса, што им је аутоматски прибавило и ниску вредносну одредницу. Оне суштински, што показује и ово истраживање, представљају знатнији и зрелији приповедачки поступак Милице Јанковић у односу на почетничку збирку, стварајући уз њен респективан опус, нарочито у родном аспекту, и неке антологијске примере приповедања који могу ући у српски књижевни канон.

Кључне речи: Милица Јанковић, међуратне збирке, систематизација тематике и мотива, родни аспект, аутобиографски дискурс.

"sgaronja@gmail.com 
Замашан приповедни опус Милице Јанковић - осам збирки приповедака - ни до данас није ваљано ишчитан, истражен, нити вреднован, чак ни у обавезујућем издању, као што је то недавно објављени зборник радова посвећен њеном опусу (2014) ${ }^{1}$. У њему су, на пример, само третиране њене прва (Исповести, 1913) и последње збирке (Међу зидовима 1932, Људи из скамије, 1937), опстале у књижевној рецепцији у последњих сто година углавном зато, што је прва, топло поздрављена од једног Скерлића, директно увела Милицу Јанковић у његову знамениту Историју новије српске књижевности (1914), док је, рецимо, последња збирка имала ту привилегију да је објављена у знаменитом плавом колу Српске књижевне задруге и захваљујући томе обезбедила ипак, неку врсту трајности у рецепцији. А између те прве и последње збирке, Милица Јанковић је написала и објавила још шест књига приповедака: Незнани јунаци (1919), Чекање (1920), Смрт и живот (1922), Плави, доброћудни вали (1929), Међу зидовима (1932), Путем (1932). Очигледно, све тежа доступност њених књига (у Народној, Универзитетској, Библиотеци града готово је прави подвиг пронаћи понеки од наведених наслова) $)^{2}$ учинила је да се рецепција приповедног опуса Милице Јанковић (у нагло пораслом интересовању за њен књижевни рад са почетком 21. века), свела на њена три романа ${ }^{3}$ и споменуте две збирке приповедака, па се она и сада може сматрати још увек непрочитаном књижевницом, поготово с обзиром на приповетку као жанр у српској књижевности.

Ако се зна да је у свом замашном опусу од осам споменутих збирки, у периоду 1913-1937, Милица Јанковић написала 87 приповедака4 (у $^{2}$ шта не убрајамо 30 фрагмената / записа из збирке Међу зидовима, као ни приче из књига за децу), онда долазимо до импресивног податка - да

\footnotetext{
${ }^{1}$ Нова реалност из сопствене собе: книжевно стваралаштво Милице Јанковић, зборник радова /уреднице Биљана Дојчиновић; Јелена Милинковић; Милена Родић/, Народна библиотека „Вук Караџић” Велико Градиште - Универзитетска библиотека „Светозар Марковић” Београд, 2014.

${ }^{2}$ У правој библиографској потрази за насловима Милице Јанковић, захваљујем се нарочито Сањи Павловић из Универзитетске библиотеке „Светозар Марковић” за сву пружену помоћ у налажењу потребних наслова, као и библиотекарима Семинара за Српску књижевност Филолошког факултета, у коме су, зачудо, сачувани најважнији наслови ове књижевнице; најзад и Малиши Станојевићу, на корисним сугестијама у вези са појединим насловима из опуса Милице Јанковић.

${ }^{3}$ Милица Јанковић је објавила следеће романе: Pre sreće (Zagreb, 1919), Плава госпођа (СК3, 1924) и Мутна и крвава (1934, друго издање 2012).

${ }^{4}$ Иако је у понеким библиографијама Милице Јанковић нотирано као засебно издање („Душица”, Сарајево, 1926), мишљења смо да је такође реч само о једној приповеци (или можда: њеном преводу са руског Чехова), у популарном издању И. Ђурђевића, где је Милица Јанковић најчешће објављивала, но ни у једном каталогу до тог издања нисмо успели да дођемо.
} 
је ова књижевница, између два светска рата, написала преко стотину дужих и краћих проза, што је готово јединствен случај у српској књижевности, иначе примарно формираној на приповедном жанру, чије је главно обележје дуго била управо приповетка. По свом опусу у српској књижевности Милица Јанковић је, пре свега, дакле приповедач са изразитим наративним нервом и даром, у жанру где се њен таленат највише и показао, уздижући се кроз поједине приповести, што ће се у овом раду показати, и у антологијске врхунце, за разлику од романа у којима су на пример, уз неоспорне врлине, уочљиве и мане, управо на композиционом плану. Са очигледном и неоспорном књижевном репутацијом стеченом између два светска рата (објављујући код најугледнијих издавача попут Цвијановића, Геце Кона, у плавом колу СКЗ), тим више је уочљив раскорак између готово полувековног заборава и скрајнутости Милице Јанковић у канонским књижевноисторијским прегледима, са последицом суштинске неишчитаности њеног приповедног опуса, јер је преко сто написаних приповедака, само по себи респектабилна чињеница за једну националну књижевност, али и замашан посао за књижевног историчара. Управо из тих разлога, определили смо се да кроз овај рад представимо једну од најчитанијих, за живота најцењенијих и по опусу најплоднијих књижевница српског језика, у овом, најмање познатом и истраженом, а обимом највећем и најзначајнијем - приповедном опусу.

Збирке приповедака Милице Јанковић

Могуће је да су животне (не)околности и болеснички удес „натерали” Милицу Јанковић да буде (само) писац, па се и тиме може објаснити тако огромна продукција, несвакидашња за наше услове, која у врло малој мери може да се сведе на „писање ради писања”. Напротив, њен разноврстан тематски опус може се сагледавати из различитих позиција, пружајући вишеструко занимљив књижевни свет у њеним приповеткама. Као одличан и проницљив посматрач живота, у најранијој младости, Милица Јанковић је теме и ликове за своје бројне приче - црпла из периода када је била здрава и покретна - чак и сви облици глагола кретањ $а$, што је била непокретнија и прикованија за постељу, у њеним причама постају све присутнији. У овом случају срећемо феномен, не само задивљујућег животног стоицизма, филозофске борбе за смисао пронађен у уметности / лепоти, већ и ону класичну улогу приче и причања, познату из Андрића - да се писањем (причом) егзистенцијално надомести оно што се нема у стварности, или барем створи илузија (потпуног) живота. И мада је у 
последњој збирци (људи из скамије) то већ било очајничко „чупање” последњих мрвица тема, често и тривијалних, или без поенте, да би се потпуно сломила физички „међу зидовима” - управо ова збирка проза истоименог назива, оригинално најављује нови, спонтано настали жанр и важан поетички заокрет у стваралаштву Милице Јанковић кроз низ фрагмената, или „знакова поред пута”, струја у српској књижевности која ће се јавити тек три-четири деценије касније, а који књижевница није имала више прилике ни времена да даље развије.

Иако је имала таквог ментора, као што је то био Јован Скерлић, који ју је увео на велика врата у српску књижевност кроз прву причу објављену у знаменитом „Српском књижевном гласнику” (1909) ${ }^{5}$, а потом, директно и у Историју новије српске књижевности (1914), захваљујући, дакле, само првој збирци приповедака (Исповести, 1913), која неоспорно има културно-историјски значај за саму Миличину књижевну биографију (као скоро једина збирка у фокусу критичарске пажње пуних сто година), но, то свакако није и најбоља збирка Милице Јанковић. ${ }^{6}$ Иако је ушла у српску књижевност уочи Првог светског рата, нема сумње да највећим делом свог стваралаштва Милица Јанковић тематски и стилски припада реалистичком дискурсу, и то оном изворном и од најбоље ковине, битно ширећи, тематски, мотивски и стилско-језички српску реалистичку приповетку, што је до данас мало запажено. Њена савременица, Исидора Секулић, па на неки начин и личност са којом је заједнички закорачила у књижевност, умела је мудро и надахнуто да оцени тај респектабилан приповедни опус поводом смрти Милице Јанковић. Исидора истиче „ретку лепоту” Миличиног приповедања, односно дар усменог приповедача („Она је писала причу као да је прича усмено, са непрестаним погледом у слушаоца"), истицала је њену уметничку моћ представљања човекове метаморфозе, затим патриотски и народни елемент приповедања, посебно у приповеткама које „обрађују проблеме наших вароши и села". 7 Најзад, управо поводом приповедног опуса Милице Јанковић, чувен је Исидорин суд о вредновању културе уопште: „Милица Јанковић нема у нашој литератури своје право место. Она је одличан приповедач. Када се смиримо, када сазремо као култура,

\footnotetext{
${ }^{5}$ „Отргнути листићи из дневника једне девојке”, објављени у Српском књижевном гласнику, 1. јула 1909. године.

${ }^{6} \mathrm{O}$ овој збирци сам више писала у својој књижевноисторијској студији Жена у српској књижевности (2010), па се овом приликом на овим причама нећемо задржавати.

${ }^{7}$ Исидора Секулић, „Сахрана Милице Јанковић”, Политика, 29. јул 1939, 7 (преузето из: Велиша Јоксимовић, „Стваралачка историја и приповедачки поступак Милице Јанковић”, у: Нова реалност из сопствене собе, зборник радова „Књижевно стваралаштво Милице Јанковић”, 2014, стр. 22.
} 
она ће то место морати да добије” (Маринковић 1977: 7). Чини се да је то „сазревање културе”, барем у погледу женског књижевног стваралаштва дошло управо са првим деценијама 21. века.

Највећи приповедни замах и уметничке домете у жанру приповетке Милица Јанковић је остварила у периоду од 1920. до 1932. године - односно, од збирки Чекање (1920) и Смрт и живот (1922), до збирке Путем (1932). У тих дванаест година перманентног књижевног стваралаштва, створен је респектабилан књижевни опус, који сем приповедног, чини и романескни, као и приче за децу. То су, истовремено, вредносно најкохерентније и најбоље збирке у њеном опусу, где је она дала и бројне антологијске приче. Жанровски искорак и последњи велики уметнички узлет Милица Јанковић, као што је напоменуто, постиже збирком Међу зидовима (1932), закључно са Људима из скамије (деценијама готово једине у фокусу пажње само због значајног издавача), збирци која већ сведочи о „кратком даху” писца и напуштању борбе - поразом пред животом.

Та уметничка размахнутост и занос животом (и поред болести која већ постаје њен сталан пратилац), најживљи утисци, сјај и снага стила, највиднији су у првој послератној, и зачудо најкохерентније компонованој збирци Милице Јанковић, Чекање (1920). Одлично одабран наслов збирке (Чекање), као мотив, троструко се варира у разноликим значењима и у различитим приповеткама. Док је у првом есејистичком и аутопоетичком запису („Час стварања”), то чекање инспирације, заправо, суштинско детектовање стваралачке кризе, као честог пратиоца многих уметника („Али ево месеци и месеци пролазе а часови стварања неће да ми дођу”), у причи „Ученица”, мотив чекања се манифестује као воља снажнија од смрти, чиме је самртница одлаже чекајући вољену особу и на трен поричући смрт у име живота; најзад, у истоименој причи („Чекање”), то је изузетно страсна љубавна прича у наговештајима (тако ретка код ове књижевнице), у којој се љубавни зов фиксирао у чекање драге особе, која се, међутим, те вечери, у смени спољашњих атмосферских прилика (ноћ, киша, пљусак) не појављује. У изузетна приповедна остварења из ове збирке такође можемо убројити и приче „Пљусак” и „У санаторијуму”, где у приповедачком - ја исказу, књижевница даје неке своје (доста ретке) моменте из прве младости, из ракурса још снажног животног оптимизма и ведрине, иако већ озбиљно начете болешћу, са честом дихотомијом телодуша (тело, које омета и душа, која би да узлети). Сасвим особеном чини нам се и приповетка „Наказа” (којој би боље стајао наслов „Глувонема”), која се тематски приближава сјајном циклусу проза Боре Станковића о „божјацима”. У атмосфери једне бање у Србији, у раскошном сликању 
пејзажа и живота бање, ауторка се фокусира на судбину „глувонеме” просјакиње и њену трагичну судбину, кроз различите мене: од девојчице, до пре времена остареле и наказне жене. У ликовном смислу (по описима природе Србије) ово је једна од најбољих приповедака Милице Јанковић. Остале приповетке (од њих, укупно 17), чине ратне приче (што стоји и у поднаслову збирке, као главна тематска одредница: „одломци из историје робовања и из историје јунаштва”). Међу њима, прича „Спасиоци”, исприповедана у мушком роду, по сучељавању и драматичности мотива (рањеник, кога спасавају два дезертера, и које, стога, чека смртна казна), може се назвати антологијском. На исти начин и са сличном снагом, бирајући провокативне мотиве из рата (Балканског и Првог светског), Милица Јанковић ствара узбудљиву ратну прозу („Инвалид”, „Отац”, „Мајка”, „Јесен”, „Редом”, „Регрут”), где се посебно истиче прича „Чарапе” (мајка доноси чарапе сину, не видевши у болници да је он заправо инвалид, без обе ноге). Најзад, и у завршници ове збирке, издваја се и четврти значењски облик речи „чекање”: то је ишчекивање ослобођења, али и најдражих мушкараца из рата, у причи „Велико чекање”. Овом збирком Милица Јанковић дала је најозбиљнији допринос српској ратној приповеци, што до сада готово уопште није уочено, нити вредновано.

Њена следећа збирка приповедака Смрт и живот („Напредак”, Београд, 1922), са својих 18 приповедака (!), редигована руком самог Скерлића ${ }^{8}$, који ју је и припремао за штампу, представља предратни рад Милице Јанковић, настао одмах након успеха прве збирке Исповести и више него наклоњеног суда великог арбитра српске књижевности пре Првог светског рата. Но, ова збирка увелико надмашује њен првенац по некој врсти тематске компактности, вредносне уједначености и стилске ослобођености, размахнутости у наративу. Збирка „Смрт и живот” у целини носи скерлићевски печат - настала очигледно на трагу прокламованих Скерлићевих критеријума, она у клицама има све оне елементе који ће развити све потоње врлине (и мане) приповедачке уметности и опуса Милице Јанковић: све приче одреда су као „срезане”, са животном снагом у исказу и видним тематским новинама. Ово су приповетке које највећим делом богате опус Милице Јанковић, али и сваку будућу антологију женске и српске приповетке.

\footnotetext{
${ }^{8}$ Скерлић је приредио за објављивање прву књигу Милице Јанковић (Исповести - његов је и наслов ове збирке), и „прегледао и уредио” приповетке за њену другу збирку Смрт и живот, која је требало да се појави у издању Цвијановића 1914. године, али је због почетка рата штампана тек 1922. године” (у издању „Напретка”). В. Јоксимовић, исто, 18. Милица Јанковић је носила неподељено дивљење за Скерлића: „И мој је учитељ био тај јаки човек, мој велики учитељ” (Јанковић 1919 б: 466).
} 
Састављена од обимних приповести аутобиографског карактера („Мој отац” или „Тетка и теча”), свој несумњив таленат, М. Јанковић приказује и у причама „исечцима” из живота, са снажном психологизацијом и атмосфером - спојем пејзажа и унутрашњег стања човековог бића, где је честа тема смрт и спровод, и то младог човека („Смрт и живот”, „Непогода"), све дато кроз добро фокусиран угао посматрања и својеврсни натурализам:

Блато, блато од неба до земље. Село с прљавим, бедним кућицама, тоне у блату, расуто по долини као разбацана гомила камења коју је нека бујица нанела и равнодушно ту оставила. Дува студени ветар. Густо блато се угиба под тешким кораком. И срце под кожухом куца узнемиреније. Има и наде за онога ко хоће да се теши: ветар обећава да ће брзо смрзнути то блато („Смрт и живот”, 31).

У насловној причи из које је преузет наведени цитат, антологијској у сваком погледу, „Смрт и живот”, без иједног сувишног коментара, Милица Јанковић слика трагичну женску судбину, нежељене невесте, у правом смислу „патнице”, која након изненадне смрти мужа, мора да напусти мужевљеву породицу, остављајући им и своје мало мушко дете, а кроз драмски добро мотивисан тренутак и „исечак” са мужевљеве сахране - са епилогом - након годину дана (кроз дијалог са младом удовицом, током путовања у колима). Срезана, бритка, ефектна, без сувишне речи и коментара, сва такорећи „скерлићевска” по дометима које је велики критичар посебно заговарао, у овој приповести Милица Јанковић се приказала као приповедач од високог артизма, али и књижевница која је већ тада уметнички проговорила о специфичној женској судбини у патријархалном свету.

На исти начин може се посматрати и прича из Првог светског рата („Случај”), у којој се Милица Јанковић показује као мајстор наратива у свакој теми: заустављена такође на зачудном, готово филмском „снимку” жена у црнини (сцени изношења одеће војника и њеном ритуалном сахрањивању „на глас да је погинуо”), из чега израста горостасна фигура оца, који не верује у гласине, да би затим у краткој ретроспективи о сину-јединцу, отишлом у „бугарски”, потом и Велики рат (који се управо завршио), прича фокусирала на очево упорно трагање за „гласом”, заправо одмотавања клупка ка истини, које открива својеврсни феномен усменог преиначења вести и њиховог нарастања до чудовишних размера (зарад прибављања себи личне важности), што све кулминира у завршној, експресивној сцени: у тренутку када потеже корбач да казни рођаку која је, нахрањена гласинама, предупредила синовљеву „погибију” откривајући да је све измислила, појављује се младић, жив и здрав из рата, што је све 
заустављено у ефектној и последњој реченици - слици оца: „А Младен стоји као камен, само му се доња вилица тресе".

Сем великих наративних целина, блиских малим романима (дужине од 50 до 70 страница, као што су споменуте приповетке „Мој отац” и „Тетка и теча”), у овој збирци, заступљене су и аутобиографске цртице, из периода њеног основног школовања, са окусом искуства (социјалне) неправде у колективу („Прва”), преко лирски интонираног реализма („На Млави”, „Догађај”, „Ђак”), датих такође у искошеном и експресивном кључу. У овој збирци Милица Јанковић започиње и особен тематски циклус, дат кроз неколико ,јадранских проза” („Загонетка”, „Пут у Цавтат”, „Доктор”), који ће она тек развити и потом предано неговати до краја живота, као неизлечиви заљубљеник у море, док део прича можемо назвати и причама-портретима (о доброћудном лудаку „дотуру” из Дубровника), најзад и неколико лирских рефлексија („Плаве очи”, „Скице”, „Никоме не требам”, „Светао час”, „Акорд”), све до патетичне апотеозе („Збогом Дубровниче!”) којом се завршава ова књига.

Разноврсни стилови / дискурси, али и тематски „измешане” приче карактеришу, не само ову збирку Милице Јанковић, већ се она може сматрати парадигматском и за све остале њене збирке. Овде је већ уочљиво одсуство осећаја за добре, суштинске (мотивске) наслове - како прича, тако и читавих збирки, односно, недостатак осећаја за тематско-стилско компоновање прича унутар једне збирке, као једне уметничке органске целине, а зарад веће „читљивости” и „проходности” њених прича, иначе вредних по себи. Тако, рецимо, ову збирку отвара можда и најслабија прича у читавој збирци (,Загонетка”), а на самом крају налази се једна од најбољих приповедака у читавом Миличином опусу - „Мој отац”.

„Мој отац” је у сваком погледу антологијска приповетка српске књижевности - са снажно проживљеним, непатвореним сликама једног срећног детињства, какве смо ретко сретали у нашој књижевности, а усред егзистенцијалних неоколности (одрастање без оца, што је лајтмотив ове прозе - усред туђе куће), са изузетно живо представљеним ликовима укућана (деде, бабе, ујака Лазара, мајке и сестара), који омогућавају девојчици изузетно срећно детињство, дато у првобитној перцепцији света где је све „чудо”, а живот испуњен и испијен до дна. Такође, и кроз аутобиографску причу „Тетка и теча” ауторка проткива неколико провокативних мотива, који и ову приповетку уздижу у сфере антологијских - контраст телесне лепоте (тетка) и божје казне (наказно, треће дете које је родила), кроз рељефне портрете својих рођака, Милица Јанковић сугестивно слика предратни Београд, његов успон пред Први светски рат, али и прве ратне 
дане са трагичним епилогом. Приповетка има захвате и рукавце једног мањег романа.

Већ из збирке Cмрт и живот могу се сагледати неке константе присутне и у каснијем приповедном опусу Милице Јанковић: најјаче су јој аутобиографске приче или приче са аутобиографском подлогом, уједначеног интензитета и квалитета, као и приповести у којима нараторка постаје објективни посматрач, сугестивно сликајући добро одабране и драмски снажно мотивисане сцене - исечке из стварности. Најслабије (не само у овој збирци) су јој ,јадранске” приче, које не прелазе путописно-репортажни жанр, док је и ова збирка, као и неке потоње, могла да прође без лирских (и углавном слабих) рефлексија и апотеоза, које су, суштински, падајући у патетику и непотребни сентиментализам (оно што је „мушка” критика једва дочекала), квариле општи повољан утисак о збирци и „најјачим” причама у целини.

Може се рећи да Милица Јанковић, што је већ примећено у критици ${ }^{9}$, овако зацртану „поетику” није унапређивала, већ ју је само тематски проширивала, пишући из креативног нагона у којем је још једино могла да налази смисао сопственог живота, не промишљајући много приповедачке или композиционе стратегије, нити финесе властитог приповедног опуса. Стога, следећа, обимом „тања” збирка из 1929. године Плави, доброћудни вали, већ носи исти манир који ће доста одмоћи рецепцији Милице Јанковић - прозе неуједначених вредности, неадекватног, помало и патетичног наслова, али са опет неколико сјајних искорака, попут приповетке са снажним аутобиографским печатом „Стојан Стевић”, о свом одрастању у предратном Београду, као и причама / портретима („Богдан”, „Кате Марћели”). Фигура (недостајућег) оца у антологијској причи „Мој отац” из збирке Смрт и живот, овде се даље развија и транспонује кроз лик „Стојана Стевића”, кроз који, међутим, уместо недостајућег оца, девојчица доживљава двоструку издају мушког/очинског принципа - неког ко се (за)волео као отац, али чија је издаја (поверења), због порока (пијанства), представљала изгубљено поверење у људе уопште. Мушкарци су уопште, код Милице Јанковић као и код Исидоре Секулић, она „срећнија половина човечанства”, чије типове Милица Јанковић слика мајсторски, остављајући најснажније странице своје прозе управо о неким најважнијим мушким личностима из свог најранијег детињства и непосредног окружења (ујак Лазар у причи „Мој отац”, „Богдан” и сл.).

${ }^{9}$ Поводом смрти Милице Јанковић о њој су писали: Павле Поповић, Сима Пандуровић, Владимир Ћоровић, Павле Стефановић, Драгиша Васић, Младен Ђуричић, Марија ИлићАгапова, Исидора Секулић. 
Збирка Плави, доброћудни вали (названа такође, по најслабијој приповеци у збирци), креће се, дакле, у наведеном тематском опсегу: сачињавају је три прозе са Јадрана, вредносно различитих учинака („Прича без сижеа”, замамног и обећавајућег, „модернистичког” наслова, као нека врста експеримента, али без јачег уметничког ефекта), прича-портрет „Кате Марћели”, која се у целокупном опусу Милице Јанковић на јадранске теме чини и најуспелијом (реч је ванбрачној кћерки неког „дубровачког госпара”), коју путница упознаје у њеним позним годинама, ванредно ефектно сликајући у виду гротеске, сав њен трагичан раскорак, почев од физичког изгледа и понашања ове жене са свешћу о „аристократском пореклу”, до једне горке ироније коју сенчи известан хуманизам према овом женском типу. Најзад и једна аутобиографска проза, са интимистичким пресецима („Са острва") приказује Милицу Јанковић као књижевницу врло истанчане интроспекције и врло модерног психолошког понирања у себе, која нам се стога чини врло успела. Најјаче приповетке и овде су оне, инспирисане раним детињством и школовањем у Београду („Стојан Стевић”, „Богдан”), којима се придружује и потпуно аутобиографски запис („Познанство са Шантићем"). Ова збирка, као узорак у малом, приказује сву хаотичност њеног рада, писање надушак и „без реда”, као и споменутог одсуства за компоновање прича у складне тематско-мотивске целине приликом припреме за објављивање.

У ову генезу приповедног рада је неопходно умешати и лични животни моменат Милице Јанковић. Залагањем најугледнијих књижевника тог времена на Коларцу је организовано књижевно вече њој у част (организатор је часопис „Мисао” тј. његова власница, Смиља Ђаковић), ${ }^{10}$ и новчано омогућено да иде на лечење у Париз, крајем 1927. године (где борави од децембра до марта-јуна 1928. године). Прво је боравила у болници, потом у приватном пансиону - када ју је посетио и Бранимир Ћосић сачинивши скицу за интервју са њом (који, иако предвиђен, нажалост, никада није објављен у његовој чувеној књизи Десет писаца - десет разговора, 1934) ${ }^{11}$. Париз знатно тематски-просторно проширује њену

\footnotetext{
${ }^{10}$ Књижевни часопис „Мисао” организовао је 1927. године књижевне вечери на којима су говорили Павле Поповић, Сима Пандуровић и Исидора Секулић, а песме су читали Велимир Живојиновић Massuka и Десанка Максимовић. Сав приход је уручила Смиља Ђаковић Милици Јанковић за њено лечење у Паризу. Велиша Јоксимовић, исто, (23). Видети и Јелена Скерлић-Ћоровић, Живот међу људима: мемоарски записи, Нови Сад, 2014, 186.

${ }^{11}$ Бранимир Ћосић, Десет писаиа, десет разговора, прир. Јован Пејчић, Службени гласник, 2012. У ово издање приређивач је први пут укључио незавршени и необјављени интервју Б. Ћосића са Милицом Јанковић, обављен у Паризу до 18. јула 1927. године (према издању Иванке Разић Удовички), стр. 141-153.
} 
приповедну уметност - уз Јадран, то су две дестинације које су видно обогатиле њен (кретањем оскудан) стваран и спољашњи свет. Ову етапу у свом животу она је приповедно пропратила такође једном од најбољих збирки Путем (1932), где у мноштво прича као место збивања уводи дакле, и Париз. Париске приче присутне су у мањој и мање успелој мери и у њеној последњој збирци Људи из скамије, као и у појединим фрагментима прозе Међу зидовима, но често различитих вредносних резултата. Као да је превелика жеља да се Париз доживи свим чулима (и да се тај град не сведе на болницу), била јача као свесна намера, од спонтаних тренутака који рађају истинску уметност. Тај „грч” да се пише о Паризу по сваку цену, стога је дао разнолике резултате и тек једна прича („Уметничке лудорије") би заслуживала назив антологијске приповетке.

Но, без обзира на изречено, нова збирка, Путем, настала након боравка у Паризу (док је још постојала нада за оздрављењем), поново је обасјала свим сјајем приповедну уметност Милице Јанковић. Објављена код угледног издавача Геце Кона, иако опет са лошим распоредом прича, она крије неколико антологијских приповедака. Ту посебно мислимо на насловну („Путем”), једну изванредну, реалистичку слику преткумановске Србије (као што је поменуто, сви глаголски облици појма кретања / путовања, постају све присутнији у прози Милице Јанковић, што је она била физички непокретнија и везанија за собу и кревет). Ту такође, пуну пажњу привлаче још неколике приче, попут аутобиографске „Позориште” (која као да је сјајан наставак приповести из детињства и прозу „Мој отац”), затим „Сликарка”, такође приповетка антологијска у сваком погледу, где нараторка у трећем лицу приповеда о жени-сликарки, неконвенционалном у сваком погледу, као жене будућности (кратка коса, цигарета, шешир), која, задивљена лепотом пејзажа са језером у позадини, уместо уживања у сликању тог призора, ненадано учествује у догађају, у којем својом изузетном самосвешћу и неустрашивошћу (за разлику од пасивних и околних посматрача, монаха - чиме је дала снажну критику религије као догме) спасава једног дављеника сигурне смрти. Овај врло необичан и модеран угао посматрања дихотомије живот-смрт, ваја и лик једне „ослобођене” жене будућности - припаднице не само нових, феминистичких струјања, у деценијама између два светска рата, већ и типа жене интелектуалке и наглашеног атеисте. И један од прозних експеримената (којима је Милица повремено волела да се позабави, барем у насловима) овог пута уродио је плодом - реч је о причи „Туђа приповетка”, која је постављена у иронијски дискурс и фокусирана као једно јавно предавање у женском удружењу, сасвим модерних и авангардних захвата и порука. Коначно, и једна „па- 
риска” прича под насловом „Уметничке лудорије” приказује у једном срећном часу сав уметнички потенцијал Милице Јанковић и показује пут којим би се развијао њен наратив да је којим случајем имала срећније (нормалније) околности живота и услове за развој сопствене приповедне уметности. Остале ,париске приче” у овој збирци не могу понети епитет успелих - заустављене на болничким доживљајима из болесничке собе („Прошла је”, ,Жена од заната”, „Секташ”, „Мала Францускиња”), тематски прегнантне, понекад сентиментално-патетичне, па чак и тривијалне и без поенте, ни у ком случају не сврставају ове теме из „вечног града” у њен успели приповедни циклус. Но, у три последње, тематски сасвим разнородне приповетке, Милица Јанковић се поново винула у саме врхове својих приповедних могућности. Реч је о необичној (може бити, такође „париској”) причи под насловом „Тровање”, где у мушком роду и ја-форми, ауторка исписује необично сугестивно (лично?) искуство на граници живота и смрти. Друга прича „Командант”, такође представља (у мушком роду) једну ратну исповест на Св. Луку 1915. (и у ратним причама, што је тема следећег поглавља, Милица Јанковић остварује свој значајан, укупно трећи и веома успели тематски циклус), док последња приповетка „Лепота” представља истинско естетско изненађење: аутобиографски заснована, ауторка као да исписује врло надахнуту и оригиналну реплику на чувену драму Боре Станковића „Коштана”. Њена јунакиња је такође млада, прелепа Циганка, играчица и певачица на сеоским вашарима, коју среће кроз неколико година као просјакињу, не препознајући је, прерано остарелу од тешког живота и бројних порођаја, чиме Милица Јанковић као да дописује Бору Станковића о трагичној пролазности и удесу жене и женске лепоте, али дајући и своје аутопоетичке ставове о естетици уопште. У приповедном опусу Милице Јанковић од почетка доминира изразита ликовност у перцепцији света - сем дара запажања, црта лица, пејзажа, ту је и ликовни дар за боје, цвеће, пејзаже и уопште, осетљивост за лепоту.

Иако објављена исте године, када и збирка Путем, прави поетички заокрет у приповедном опусу Милице Јанковић представља књига, први пут одлично одабраног наслова - Међу зидовима (1932) - збирка кратких прозних записа, што чини њен опус доврхуњеним и занимљивим управо у једном новооткривеном поетичком путу и правцу - који води ка сасвим модерном изразу. Иако антиципира потпуни пораз пред животом, ова проза је победа уметности Милице Јанковић, која се суштински приближава српској књижевности која ће се писати крајем седамдесетих и осамдесетих година 20. века, и која тек треба да заслужи једну подробнију анализу савремених истраживача. Попут кроки цртежа, сачињена од 
фрагмената, сећања, асоцијација, рефлексија са наглашеним психолошким контекстом, ове прозе представљају њен несвестан заокрет од реализма ка модернизму.

У ових 30 прозних фрагмената, Милица Јанковић потпуно помера свој наратив са спољашњег ка унутрашњем, у потпуном одустајању од фикције, нарације, сведеном на лично, ,за себе”. То је, заправо, бележење различитих психолошких стања субјекта у егзистенцијалној тескоби („Међу зидовима”, „Мој видик” „Молитва” са отвореним скептицизмом, штавише одсуством вере у Бога), у интроспекцији кроз изузетно танане, лирске и метафизичке симболе (птице, дрвеће, годишња доба) и готово надраженим чулним опажајима (звуци споља). Стварајући прозу пуну атмосфере и симбола, пледирајући за наизглед невидљив живот, пун непомерљивих ствари (прозор собе, шаре леда на прозорима, рађање пролећа кроз раст дрвцета), иза којих се назире сама суштина живота, повремено прожета сећањима (опет изузетно снажни и живи фрагменти из детињства, са студија у Минхену, или недавног боравка у Паризу), често и са психолошким контекстом јеткости и огорчености (пред животом), припуштајући тек понеке људске гласове у свест или посете неименованих пријатељица, Милица Јанковић успева да створи понекад праве прозне медаљоне („Врапци”, „Ледене слике”, „Шљивица”, „Почетак”, „Жеља”, „Ноћас”, „Плави прозор”), још увек трагајући за осмехом („Ретка посета”), или лепотом, од које начас живне и која још једино може да је одушеви („Последње што код културнога човека умире то је осећање лепога” каже у запису „Једино добро”, 37). Ова проза се симболично завршава реченицом: „Јер наде нема” („Плави прозор”), па на неки начин овај исказ симболично заокружује не само збирку Међу зидовима, већ и читав животни круг и приповедни опус Милице Јанковић.

Ипак, и после ове, на неки начин тестаментарне прозе, Милица Јанковић је смогла снаге и написала још једну, своју последњу књигу - збирку приповедака Људи из скамије (1937) - где су сећања на школске дане тек грчевита борба за последњи нађени смисао (живота) у писању, који се неумитно гаси. Људи из скамије - сведочи о паду свих биолошких снага, „чупање” из себе тема, оживљавајући време пуно заноса (када је све било супротно од садашњице) - у школском добу, где је сећање последњи механизам одбране и оживљавања оне енергије здравља и кретања, када је све било нормално, а живот пун обећавајућих чуда (која су сва одреда изневерила), чиме се у ствари књижевница упустила у своју последњу борбу, надомешћујући (неподношљиву) садашњицу и стварност сопствене егзистенције оживљавањем већ дебелих талога бивше (срећне) прошлости. 
И док је њена последња збирка Људи из скамије (можда и најзапаженија, зато је што је била последња, објављена у плавим корицама СКЗ - чиме је Милица Јанковић постала једна књижевница која се два пута појавила у плавим корицама) $)^{12}$ само једно гребање по већ увелико празном чанку, очајнички покушај да се пише, када је већ и здела животног искуства испражњена, упркос још огромном духовном витализму, животном стоицизму, њене приче у првој половини књиге, зачуђујуће једнообразне структуре, доиста се налазе на граници приповедног дискурса за децу и омладину (па многи, с правом, сврставају ову збирку и у дечију књижевност). ${ }^{13}$

У тих својих петнаест краћих прича, у добро познатом тематском опсегу (аутобиографске, реалистичке, јадранске, париске), Милица Јанковић се, као што је речено, претежно задржава на добу гимназијског школовања (у Вишој девојачкој школи у Београду), нажалост, углавном обрађујући понекад и (баналне) теме са школских часова, засноване на анегдоти или причи без поенте. Можда би се у том смислу успелом могла назвати прича „Први дан” (где се у лику Загорке - често име које себи даје нараторка у причама из детињства), доста пластично описује Београд уочи Првог светског рата и друштвени миље тог времена. (Још када се томе дода, да је рецимо, канонско издање Сто дела српске књижевности, Матице српске од целокупног приповедног опуса М. Јанковић, садржавало само једну причу Милице Јанковић - „Најгори разред” ${ }^{14}$ управо из ове књиге - пренете, уз слабу причу „Мало срце” (из Исповести) и у антологију Рајка Лукача ${ }^{15}$, можемо схватити размере, колико је ова књижевница вишеструко и непремостиво „оштећена” у рецепцији и савременој историји српске књижевности $)^{16}$. Слабим нам се чине и „париске приче” („Моји

${ }^{12}$ Марија Илић Агапова, у чланку „Случај Милице Јанковић или Победа духа над материјом”, пишући о књизи људи из скамије, истиче Миличину уметност супротстављања смрти: „Преживети живот, то је уметност посебна и велика. Преживети га отимајући га од болести, то је подвиг који се обнавља сваког дана" (Агапова 1938: 291). В. Јоксимовић, исто, 23. Сем ове књиге, Милица Јанковић је претходно у плавом колу СКЗ објавила и роман Плава госnођа (1924).

${ }^{13}$ Тијана Тропин, „Милица Јанковић и књижевност за децу”, Нова реалност из сопствене собе: зборник о Милици Јанковић, 2015, стр. 2013-214.

${ }^{14}$ Сто дела српске књижевности, Матица српска, књ. 12, Нови Сад, 1963.

${ }^{15}$ Рајко Лукач, Антологија приповедака српских кюижевнииа, Београд, Zepter book world, 2003.

16 Према истраживањима Малише Станојевића, негативна критика, започета од романа Плава госпођа из пера Милана Богдановића, као и Веселина Маслеше, пренела се механички и на потоње критичаре, пре свих Велибора Глигорића, који својим вредносним судом још више минимализује дело Милице Јанковић, а да га није и прочитао (видети: мој рад „Милица Јанковић у светлу истраживања Малише Станојевића”, „Наслеђе”, бр. 30, Филолошко-уметнички факултет, Крагујевац, стр. 15-16). 
пријатељи” - о голубовима из болничке собе, „Цвећарница”), као и једно сећање на Минхен без поенте (,Лав”), док једна јадранска прича („Њина Васиљевна"), такође представља причу / портрет, која не домашује сличне из ранијих збирки, а сличан утисак оставља и помало патетична приповест из рата. („Попрсје” - о скривању бисте краља Петра пред окупатором.) Но, поново ће у пуном сјају заблистати њено перо у причама из другог дела збирке - пре свих, то је проза „Зидари”, где је у срезаном реалистичком исечку / слици предратног Београда и сиротињског живота у заједничким дворишним становима, са прецизним скицирањем различитих карактера и људских судбина (чиме је ова проза сродна са једном од њених најранијих прича „Отргнути листићи из дневника једне девојке”) ванредно поентиран - кроз призор смрти радника-зидара, усред те свакодневице живота, која се догађа пред дететом као сведоком, а што ће обележити њено зрење. На високом уметничком нивоу је и прича „Утеха” - можда и траг личног, сентименталног сећања - долазак учитељице на сахрану момка који јој је некада био удварач. Изузетан реалистички проседе и животворна проза, још једном је уздигла Милицу Јанковић, из скоро непостојећег тела, у астралне и супериорне просторе духовне креативности.

Са збирком Људи из скамије, завршио се један опус, а ускоро (кроз две године) у Нишкој бањи и живот Милице Јанковић, као јединствен пример стоичке борбе кроз уметност за смисао, а као пример немирења духа са ограниченошћу тела.

Милица Јанковић и Исидора Секулић - два коинцидентна укрштаја 1919. године

У тами сањам један сунчани дан. Са сунием ће доћи час стварања. Видим осмехе радости, сузе радости и бледо ћутане радости. У тами их видим. У светлости их видим. У светлости треба да их видим [...] Надати се у болима то је крваво надање, а чекати у нераду то је најдуже чекање.

Милица Јанковић, „Час стварања”, 1920.

Приметно је да, идући хронолошким редом - нисмо до сада говорили о две најраније збирке приповедака, које је Милица Јанковић објавила непосредно након Првог светског рата, обе из 1919. године: Незнани јунаци које, уз приповетку Калуђер из Русије, издвајамо посебно, јер имају карактеристике битне за генезу развоја приповедне уметности Милице Јанковић са аутобиографском подлогом. Управо, ова два издања су инте- 
ресантна и са становишта поређења са једном другом великом савременицом Милице Јанковић - Исидором Секулић. Заједничко време у коме су стварале, сличан тематски опсег у приповедном опусу, учинио је да се ове две књижевнице у истој, 1919. години, коинцидентно „сретну”, да би им се од тада путеви заувек разишли. Као што је напоменуто, мало запажен је допринос Милице Јанковић нашој ратној причи (из Балканских и Првог светског рата), којима је она (уз приче из каснијих збирки), дала немали прилог српској књижевности.

У том смислу, збирка Незнани јунаци (1919), објављена код угледног издавача Светислава Б. Цвијановића са свега четири приче, непосредно након Великог рата, разноликих уметничких домета (што је поетичка константа збирки М. Јанковић), представља зачетак њене ратне прозе, успешно проширене нарочито у наредној збирци, Чекање (1920). ${ }^{17}$ Квалитетом се издваја насловна прича од скоро 50 страница („Незнани јунаци”). Она антиципира тему која ће доминирати овом збирком - судбину жена „у позадини” током Балканског рата (који је иначе, мање заступљен у српској књижевности у односу на Велики рат). Главна јунакиња Лена је грчко-цинцарског порекла, и њена узбудљива животна прича (о породици и како је удајом дошла у Србију) заузима већи део ретроспективног приповедања у овој прози. Но, дајући слику српског села усред рата, кроз реалистичке и карактеристичне „исечке”, главни приповедни рукавац Милица Јанковић плете око Лениног сина, Боже, и мајчиног ишчекивања да јој се син врати из рата, уз који се плету и остале судбине жена у ратном времену. Топлина и катарзична лепота красе сам крај приче (за који, у „хоризонту очекивања” слутимо као трагичан) поентиран „неочекивано” срећним завршетком: повратком војника, тако ретким осећањем среће у њеним прозама, па и у нашој књижевности у целини. (Још једна изузетна прича тематски јој блиска - „Случај”, такође у завршници има срећан крај - повратак сина из рата, већ проглашеног „гласинама” за погинулог, кога у овом случају, ишчекује отац).

За разлику од претходне приче, проза „Рат” (са насловом као општим местом), потпуно је аутобиографска. Реч је такође о Балканском рату, кроз сцену повратка књижевнице у село, мајци и сестрама, након проглашења мобилизације. Изванредни реалистички пејзажи и пасажи, на неки начин су наружени патетичним пасусима / апотеозама српским војницима, који

${ }^{17}$ У разговору са Б. Ћосићем, Милица Јанковић наводи да је Цвијановићу дала много већу збирку ратних прича, из којих је он одабрао само наведене четири, због чега је променила издавача. Остале, необјављене, су касније испуниле следећу збирку Чекање (1920). Бранимир Ћосић, Десет писаца - десет разговора, 2012. стр. 148. 
су кренули масовно у рат; и у овој прози доминира поново слика живота српског села „у позадини”, нарочито слика жена и њихових судбина, након одласка мушкараца у рат. Пад у неку врсту памфлета представља, међутим, следећа проза, „После рата”, у којој је Милица Јанковић (непотребно) у високопатосном стилу дала једну врсту одушка победи, али и апел да се не забораве инвалиди, остали након рата, који „просе”; по овој тематици (и само по њој), она се ближи Лази Лазаревићу. Најзад, збирку заокружује антологијска прича, која је могла стајати и на почетку књиге - „Колера” - у свему савршена и срезана слика рата из ракурса мушкарца-војника ${ }^{18}$, награђена на „првом конкурсу Политике за (ратну) причу” (Јоксимовић 2014: 24)

Ратне приче Милице Јанковић, објављене у засебној збирци, значајне су из још једног аспекта - исте године још једна (будућа велика) књижевница, Исидора Секулић, објављује такође своју ратну прозу Из прошлости (и није први пут да ће им се тих година животни и књижевно-тематски путеви укрстити). Када бисмо упоредили ове две књиге најзначајнијих књижевница које су се појавиле у предвечерје Првог светског рата у српској књижевности (према суду и самог Скерлића), можемо констатовати да су обе, на неки начин, имале уметничку потребу да искажу обол према ратним темама и великој националној жртви поднетој у балканским и Великом рату. За разлику од Исидоре, која је више осећала тај морални дуг у својој обимној књизи прозе, као неку врсту уметничког ангажмана (српско питање Срба „из прека”; приказани са доста патетике, троми и дуги, „научни” дијалози ликова), Милица Јанковић у најбољим примерима (укључујући и оне ратне приче које ће доцније написати), пише са исконским патриотизмом, дајући кроз ефектне исечке ратних призора, драматичне ратне секвенце, често у мушком роду (као туђа казивања), и у том смислу праву реалистичку, експресивну и аутентичнију ратну прозу.

Најзад, у тематско-хронолошком смислу, са којим би можда могло и да се почне у анализи приповедног опуса Милице Јанковић, сасвим особено стоји њена проза Калуђер из Русије, такође објављена 1919. године (у малој библиотеци И. Ђурђевића, у Сарајеву), која је у многим библиографијама „на невиђено” проглашавана романом. То је, у ствари, не много обимна приповетка (данас прави раритет, минијатурног формата, обима 47 страница), са љубавном тематиком, али само у смислу егзистенцијалног преиспитивања себе и односа према Другом - важном за рану приповедну

\footnotetext{
${ }^{18}$ Причу је испричао Божа Павловић, ујак Милене Павловић Барили, и блиски рођак Милице Јанковић (Миличина баба и деда Милене Павловић Барили, Стојан Павловић, били су рођени сестра и брат).
} 
фазу Милице Јанковић. Реч је о преписци младе девојке са једним монахом из Русије - а ради вежбања (руског) језика - кроз коју се веома добро може сагледати комплетан психолошки профил Милице Јанковић (нема сумње да је у питању немарно прикривен лични доживљај) - девојке, прилично самосвесне, крутих моралних норми и нихилистички настројене према религији (атеисте по уверењу), у погледу емоција веома строге према себи - са низом занимљиво постављених питања из вере и филозофије у преписци са младим монахом. Високо постављених, готово аристократских начела пред (прозаичним) животом, које у преписци тражи од Другог, да би откривала и себе, неминовно изазивајући интерес супротне (мушке) стране као жена, Милица Јанковић објављује ову приповетку одмах након рата (1919), са наглашеним годинама када се зачетак ове преписке и духовне везе дешавао (1904), а са епилогом о судбинском мимоилажењу ово двоје младих људи у стварности - у времену и простору - који се никада нису срели, што је могуће, додатно иницирало књижевницу, да све напише и објави као приповетку (нарочито након вести о смрти младог монаха од туберкулозе, следеће 1905. године). То је, може бити, лабудова љубавна проза Милице Јанковић - њен обрачун са надама и сновима те врсте (када је већ и она постала болесник) - јер условно, љубавних тема, чак ни њихових наговештаја, касније нема (или их има тек у минималној мери, у њеним потоњим приповеткама).

Коинцидентном случајношћу могло би се назвати то што су се путеви Исидоре Секулић и Милице Јанковић још једном тематско-поетички и овде укрстили. Када се пореди приповетка Милице Јанковић „Калуђер из Русије”, са романом Исидоре Секулић Ђакон Богородичине иркве - који се појављују исте године (1919), код истог издавача (!) Игњата Ђурђевића у Сарајеву, можемо установити низ коинцидентних сличности, али и разлика (пре свега у жанровском смислу и по начину обликовања грађе), те поетичких константи заједничких за обе књижевнице. Пре свега, роман Исидоре Секулић обимом, сложеношћу композиције и дубином захваћених тема (тако ретких за српски роман с почетка 20. века), уметнички увелико надмашује приповетку Милице Јанковић, али истовремено, готово су зачуђујуће сличности теме и начина њене обраде, низ психолошких елемената, као и ставови у религијско-филозофској равни, на којима се заснивају обе прозе, али и са битним разликама у решавању овог сложеног емотивног питања, између самих књижевница, но са истоветним исходом (зашто до „везе” ипак не долази). Док Исидорина јунакиња „постварење” те љубави у Богу са Другим, жели да реализује и на чисто еротској равни и у стварности (и у вечности), јунакиња Милице Јанковић (њен алтер его), 
одбија од себе било какву могућност да дође до ближег контакта, чак и физичког сусрета, и све остаје у равни преписке (са иницијативом самог калуђера из Русије, који долази да лично упозна своју кореспонденткињу, не налазећи је). Другим речима, иако различитих назора у разрешавању овог питања у прози (и у животу), обе књижевнице (тј. њихове јунакиње - њихов алтер его) спаја једна дубинска и слична карактеристика: да јаке жени себи достојне и духовно равне мушкарце проналазе само у свештеницима (,продубљеним мушкарцима” у духовном смислу), па тиме само и у нуминозној љубави, која је - немогућа. ${ }^{19}$

Приповедни опус - једна могућа аутобиографија

Има догађаја који су ми се десили давно, али који су моји, који су ми блиски као јучерашњица; а има их таквих у којима ја више нисам ја, у којима сам ја ,она" и који ми се чине као нека тужна прича коју сам негде давно прочитала.

Милица Јанковић (,Ученица”, 1920)

Из скромности није написала биографију.

Станислав Винавер

С обзиром на то да је познато да Милица Јанковић није волела да прича о себи (то изричито наглашавајући и у свом једином и необјављеном интервјуу са Бранимиром Ћосићем), ${ }^{20}$ да, такође, није волела ни да се слика - управо њена приповедна проза, најмање позната савременом читаоцу - учинила нам се не само као репрезентативни део њеног опуса (уз романе, критике, дечију прозу), већ и као једна идеална и „скривена” аутобиографија ${ }^{21}$, често и без мистификације исписана сага о сопственом

\footnotetext{
${ }^{19}$ У новије време овом приповетком се подробније бави Владимир Ђурић у раду „Калућер из Русије - аутофикционални портрет Милице Јанковић”, Кьиженство: теорија и историја женске къижевности на српском језику до 1915. године, зборник радова, Филолошки факултет, Београд, 2015, стр. 275-291.

${ }^{20}$ Бранимир Ћосић, Десет писаиа - десет разговора, 2012, стр. 147-148.

${ }^{21}$ Уводећи за њену прозу термин ,аутофикција”, Владимир Ђурић, полазећи од Леженове теорије (у студији Аутобиографски уговор, о троструком идентитету писца (ауторском имену, приповедачу и јунаку у прози (који нема исто име са аутором, мада је реч о његовом животу), закључује: „Уграђујући чињенице из сопственог живота у своје текстове, Милица Јанковић се непрестано поиграва могућностима фактографског и фикционалног, те на тај начин вешто мистификује сопствени идентитет.” (В. Ђурић, „Калуђер из Русије” или аутофикционални портрет Милице Јанковић”, „Књиженство: теорија и историја женске књижевности на српском језику до 1915. године”, зборник радова, Филолошки факултет, Београд, 2015, 280-282.)
} 
животном путу, личностима из породице, окружењу и једном времену. Нескривено аутобиографско - ја, налази се у више од половине онога што је написала, а по квалитету и обиму то је и најважнији и најбољи део њене приповедне уметности. ${ }^{22}$ Живот (и њен удес) као литература, и литература као живот, можда се највише могу применити управо у случају Милице Јанковић. Уз драгоцене узгредне, и сасвим недавно обелодањене мемоарске забелешке о њеној личности (Јелена Скерлић-Ћоровић), или појединим (ретко) изреченим и сачуваним аутопоетичким ставовима, уз већ познати и недовршени интервју Бранимира Ћосића са њом, може се реконструисати у прилично доброј мери њен живот и рад, с тим што се дефинитивно сав дух и добар део биографије Милице Јанковић, најбоље може ишчитати „њом самом” управо у њених стотинак написаних и објављених приповедака.

Поставља се питање откуд толика ригидност и отклон према сопственој биографији, у чему Милица Јанковић није редак случај (довољно је напоменути да је и Иво Андрић, такође са ужасом тврдио да је биографија непотребна у делу писца $)^{23}$. То се може објаснити истоветним психолошким агенсом - тај ужас од сопствене (стварне) биографије, трауматизоване раним детињством или првом младошћу, замењен је ставом о „незанимљивости”, па и „неподобности” личне биографије (у односу на потоњи књижевни успех), која би само „нарушила” остварени свет фикције у њиховом књижевном делу. Но, док је Андрић, на пример, углавном остао доследан овом ставу (готово ништа из његовог обимног приповедног опуса или романа, не може се подвести под „аутобиографско”), код Милице Јанковић је управо све супротно. Пре него што покажемо - да је целог свог живота, у приповеткама, Милица Јанковић исписивала углавном, личну биографску путању и своје (душевне) фазе, стварајући јединствену, па у многој мери и из овог угла сагледану - крајње

\footnotetext{
${ }^{22}$ Правећи разлику између исповедног и аутобиографског обрасца поводом поезије Данице Марковић, Снежана Калинић је недвосмислено маркирала оба обрасца у (женској) поезији и прози, с тим што се приповедна проза Милице Јанковић, може сматрати аутобиографском, односно, „у исти мах отвара питање који је минимум искрености потребан да би се једно дело могло тумачити као лично и аутобиографско", што релативизује и сама књижевница Милица Јанковић у појединим приповеткама („Прва” и сл.). Видети: С. Калинић, „Нечисте жуди”, „минуле цвети” и „склопљени Верлен”: интимистички елементи поезије Данице Марковић, Кьиженство: теорија и историја женске књижевности на српском језику до 1915. године, зборник радова, Филолошки факултет, Београд, 2015, стр. 264.

${ }^{23}$ Милица Јанковић и Иво Андрић су у истој едицији „Књижевног југа” и исте године објавили своја прва послератна дела: Милица Јанковић роман (Пре среће, 1919), Иво Андрић, Ex ponto (1919). Видети и Жанета Ђукић Перишић, Писаи и прича: стваралачка биографија Иве Андрића, Нови Сад, 2012, стр. 21-22.
} 
провокативну аутобиографију у приповедној прози, ослонићемо се и на неке њене (ретке) аутопоетичке ставове о себи или свом писању, које је поверавала кроз писма интимним пријатељицама, међу којима су посебно важни недавно обелодањени мемоарски списи Јелене Скерлић Ћоровић ${ }^{24}$, или кроз ретке исказе у самим прозама (и наведеном интервјуу са Бранимиром Ћосићем). Пишући о Милици Јанковић, тако, њена блиска пријатељица Јелена Скерлић Ћоровић, даје можда и најлуциднији суд о генези приповедног света и жанра приповетке Милице Јанковић:

Имала је услове да постане велика књижевница, да јој усуд није доделио претешку судбину. Везана за постељу, оскудна у доживљајима, она сама, препричавајући своје детињство и младост, поставила је на безазлен један начин мрачну тему неслоге родитеља, осиромашења које доводи до раставе њихове, судбину деце која падају на терет родбини (Скерлић-Ћоровић 2014: 140).

На другом месту Јелена Скерлић Ћоровић готово дословно (и с правом) понавља исту констатацију, о извесној „осиромашености” тематике њених приповедака, сведених већином на „,аутобиографско”: „[...] оскудица личних доживљаја ма какве друге врсте, немогућност чак ни посматрања туђих збивања" (Скерлић-Ћоровић 2014: 142). По истом сведочанству, Милица Јанковић је свој књижевни успех примила „врло уздржано - никада себе није прецењивала" (Скерлић-Ћоровић 2014: 141). И њени књижевни почеци и преписка са Скерлићем то доказују (из претеране скромности потписивање првих прича псеудонимом Л. М., односно Лепосава Михајловић, и читав „случај” око тог псеудонима). ${ }^{25}$ Такође, та врста самопорицања себе и сопствене књижевне уметности, видна је и у овом аутопоетичком исказу: „Да ме болест не натерује на зараду, престала бих да пишем” и даље: „Нажалост, Скерлић није више жив. Колико је само излишнога он из мојих првих ствари избацио.” Или: „Колико је Исидора напредовала, а колико сам ја заостала” (СкерлићЋоровић 2014: 141-142).

Из ових сведочанстава сестре Јована Скерлића, вреди навести још неколико њених луцидних запажања о личности Милице Јанковић, а коју чине три основне духовне константе: Лепота (аристократизам духа) - Љу-

\footnotetext{
${ }^{24}$ Јелена Скерлић Ћоровић, Живот међу људима: мемоарски записи, приредила Зорица Хаџић, Академска књига, Нови Сад, 2014.

${ }^{25}$ Лепосава Михајловић је псеудоним који је млада Милица Јанковић преузела у част свог рано преминулог ујака Лазара Михајловића. Видети: Марија Илић Агапова, у чланку „Случај Милице Јанковић или Победа духа над материјом”, Београдске општинске новине, $1938,291$.
} 
бав (према људима, природи и животу уопште) - Атеизам (нихилизам) у вери. Тако на једном месту Јелена Скерлић Ћоровић пише:

Пуна полета и оправдане амбиције Милица је решена да себи припреми достојан живот, да обухвати оно што је узвишено и лепо у њему. Посвећује се студији сликарства и оспособивши се у Београду у школи Ристе и Бете Вукановић добија место предавача цртања у Крагујевцу. О распусту одлази у Минхен на продубљење студија [...] (Скерлић-Ћоровић 2014: 140).

Из преписке коју наводи Јелена Скерлић-Ћоровић, уочљиве су још две константе њене уметничке личности: „Ево једног њеног писма (Милице Јанковић) у којем је она сва: и њена с малим задовољена жеђ за лепотом, и нарочито саосећање према човеку до самозаборава [...]" (Скерлић-Ћоровић 2014: 142-143), као и једна Миличина карактеристична реченица: „Ја увек нађем да некога много волим, а онда посао споредна ствар" (Скерлић-Ћоровић 2014: 142). Или, у закључку једног писма Јелени Скерлић Ћоровић: „Волим Вас неком чудном лепом љубављу која није највећа, али је друкчија него према свима другима" (Скерлић-Ћоровић 2014: 144). Најзад, већ у младости, осведочени атеиста, а поготово на крају животног пута, када из Милице избија својеврсни нихилизам и горчина, Јелена Скерлић Ћоровић заокружује портрет ове личности: „Само што она није имала ни утеху вере, нити се заваравала надом у други свет и у неку накнаду за толике патње. По томе, по том неверовању баш, наизглед парадоксално, била је не само мученица него и светица" (Скерлић-Ћоровић 2014: 144).

Управо, читајући у овом кључу приповетке Милице Јанковић, учиниле су нам се као њена савршена, „скривена” аутобиографија, али и вредно књижевно штиво у оквиру српске књижевности, много вредније од оног што је и ауторка у својеврсном самопорицању о себи рекла, а у томе је на један површан начин подржала и официјелна књижевна критика.

Стога, у сагледавању њеног опуса у овом кључу, ишчитавамо једну сложену психолошку ситуацију писања као механизам стварања смисла и „одбране” од живота - понирањем у чаробан свет детињства, у коме је списатељица акумулирала, очигледно, највиталнији део своје личности у нимало лаком животном путу који јој се спремао, чије је касније велике и реалне тегобе (болести и непокретности) савладавала управо кроз смисао уметничког, књижевног стварања, уз вечити комплекс недостатка очеве фигуре, и уопште мушког заштитника, до топле и рељефне слике и портрета ужих и ширих чланова породице (мајка, ујак Лазар, баба, деда, сестре, тетка и теча), али средине (Велико Градиште, Београд, нарочито онај пре Првог светског рата), из периода школовања, као и најинтензивније 
проживљене догађаје непосредно уочи Првог светског рата, током рата (ратне секвенце, које спадају у најуспелије, као и преткумановске Србије) и непосредно након њега. Рефлекс девојачког доба и развијања талената (кроз сликарски и учитељски позив, љубав у лирским рефлексијама, чежњу за породицом), најзад смењују тематски и просторно различити предели, сагледани кроз призму болести (Дубровник, Јадран, Париз), да би потом преостали само зидови собе.

Са низом снажно окарактерисаних ликова и психолошких типова из њеног непосредног окружења (снажно доживљених - тачно је запажање Јелене Скерлић: „што није лично спознала, без маште, она није умела ни да опише"), у тој прози сугестивно ће продефиловати, кроз суптилан унутрашњи духовни развој једне осетљиве, надарене и натпросечно талентоване девојке (сликарство и писање) у потрази за собом, истовремено и средине где се родила и одрастала, сазревала и боравила (кроз путовања у потрази за леком), читава једна епоха преткумановске Србије, где је са посебном снагом дато српско село, али и незаборавне слике београдске вароши пре Великог рата, најзад и ратна збивања, да би се у личној генези (осакаћене породице и латентног недостатка оца и коначној „издаји” и разочарању у мушки ауторитет), у вечитој оскудици, али чудесном снагом њен дух увек издизао у аристократске висине, проналазећи их у стварности у сунчаним јадранским пејзажима, мору и господственом Дубровнику, најзад и у вреви париских булевара. Потпуно аутобиографске су и приповетке о „учитељском животу”, тј. боравку на селу у кући сестара учитељица („Догађај”, „На Млави” - у којој је, у шетњи са сестрином девојчицом, видљив рефлекс потиснуте љубави према породичном окриљу, и сопственој неостварености у материнству).

Последњу фазу њеног живота и писања покрива у целини - болест, која иницира њена два нова тематска круга, која показују сву грчевитост борбе, једног изузетно стоичког духа, не само за опстанак, већ и за виши смисао који мора да се нађе у животу. То су њене јадранске и париске теме, простори колико компатибилни са извесном отменошћу њеног духа, толико и практични, у које се упутила тражећи лека својој болести. Но, ти екскурси су битни јер се књижевница, самом чињеницом промене простора, није предавала. Они носе обележја ограничених, понекад грчевито тражених тема - сусрета на путовању, портрета необичних личности и судбина, слика пејзажа, понекад и репортажних, тек понекад и дубље психологизације, тад несвесно на трагу модерне књижевности. У том смислу, јадранске теме и Јадран као хронотоп среће, остају за Милицу Јанковић оваплоћени (и ликовни) симбол живота, какав једино и заслужује 
да се назива животом, а плава боја неприкосновено постаје ликовни знак свеколиког Миличиног прозног стваралаштва, насловљавања њених проза на свим жанровским нивоима: романом (Плава госпођа), збирком (Плави, доброћудни вали), прозом (Плави прозор). У париским темама, већ је видан недостатак даха, једна физичка изнуреност, клонуће духа, али и тражење тема о вечном граду по сваку цену - и ма колико овде пратили дух Милице Јанковић (догађаји и судбине из ракурса болничког кревета, болеснице које је окружују), тек, ретки су у овим аутобиографским причама њени узлети у истинску уметност (,Уметничке лудорије”).

Свет њених приповедака настајао је истински из (аутобиографског) центра и њеног изразито развијеног ликовног и перцептивног видокруга - оне се не мењају, не усавршавају, не експериментише се, већ их она само тематски проширују новим просторима и ограниченим искуствима. Од чари детињства, која је у ствари представљала највиталнији пртљаг живота из ког је црпла снагу, чини се, за читаву животну борбу која ју је чекала, преко љубавне тематике и трагања за собом и сопственим идентитетом, кроз љубав за Другог (Исповести, Калуђер из Русије), преткумановске Србије и малог Београда у којем је искусила сву горчину сиротињских дворишних станова и мукотрпног школовања, са социјално израженим неправдама, преко сазревања током ратних и личних страдања (болести), кратког учитељевања и боравка по селима код сестара-учитељица, кроз посматрање живота других и сопственог, до грчевите борбе за смисао кроз освајање нових простора (Јадран, Париз) за лечење и писање, до копања по сећањима, већ прошлог (бившег) живота (људи из скамије), до потпуне капитулације пред тим истим животом (Међу зидовима). То би могао да се назове аутобиографски круг Милице Јанковић описан у њеним приповеткама.

Приметно је, да је од књижевних пријатељстава која је неговала, само једно преточила у (путописну) рефлексију: причу о Алекси Шантићу (1929). Такође, један важан сегмент њеног живота и уметничког рада, можда се крије и у изузетној приповеци „Сликарка”, првобитно објављеној у часопису „Мисао” (1930), чиме би се и део њеног неоспорног ликовног талента могао сматрати аутобиографски дотакнутим. У рукопису Милице Јанковић, остале су и две занимљиве приче које би могле бити значајна допуна за овај аутобиографски експеримент: то су „Прича из Минхена (Професор Ажбе)” и „Госпођа Анка Анђелковићка” (Јоксимовић 2014: 27-28). Ове две приповести управо попуњавају онај део живота Милице Јанковић, који није непосредно дотицан у њеним објављеним збиркама 
приповедака: то је период школовања на студијама сликарства у Минхену ${ }^{26}$ (постоји само једна цртица из тог периода у збирци Међу зидовима, „Два друга” и прича „Лав” у Људи из скамије), као и период рада као наставнице цртања у Крагујевцу (1903-1907) обједињен и „покривен” управо причом (портретом) госпође Анке Анђелковић. ${ }^{27}$

Иако је Милица Јанковић кроз своје приповедне збирке исписивала увек ,једну књигу”, квалитативно се не мењајући (сем у претпоследњој збирци Међу зидовима) - разноврсни дискурси, као и тематска разноврсност говоре о њеним изузетним врлинама као приповедача, али и манама, што је одмогло или одложило њену правовремену рецепцију у историји српске књижевности. Уметнички најзначајнији део њених приповетки чине приче на аутобиографској подлози, као и приче тематски обједињене око београдског живота пре Великог рата, ратне приче, као и јадранске и париске теме. Квалитативне искораке представљају приповетке које имају позицију приповедача дату у мушком роду (ратне приче - међу њима су многе антологијског квалитета), док нарочит модернистички домет представљају лирске цртице Међу зидовима, па на овај начин, приповетка Милице Јанковић постаје вишеструко занимљива за истраживања из родног дискурса. Са историјског и друштвеног аспекта, живот Милице Јанковић, завршио се уочи самог Другог светског рата (1939) године, а нова идеолошка ера која је дошла, не само да је збрисала епоху која јој је претходила, него и људе који у новој културној клими нису могли да наставе континуитет предратне књижевности, која је уз то и темељно идеолошки прочишћена. Уз тај, формално историјско-идеолошки моменат, свакако да је потпуном одсуству рецепције њеног дела након Другог светског рата, пресудило и неколико формално-структурних елемената естетске природе. Пре свега, њено обимно и ,разбацано” дело, самим њеним физичким нестанком, више нико није сакупио, прештампао, нити објединио и учинио доступнијим, а поготово темељно ишчитао. До седамдесетих година прошлог века ${ }^{28}$ није било иоле никог ко би се упустио у захтевно и обимно ишчитавање већ тад тешко доступних књига Милице Јанковић. Тако је о

${ }^{26}$ Рукопис „Прича из Минхена” није датован, има 55 страница, исписаних на четвртини табака и посвећен је сликарки Бети Вукановић. Рукопис је описала Смиљана Стојановић у тексту „Ажбетова школа”, који је 1987. године објављен на словеначком језику у листу Наши разгледи. Није јасно где се данас рукопис налази (цитат: В. Јоксимовић 2015: 27).

${ }^{27}$ Причу Милице Јанковић „Госпођа Анка Анђелковић”, објавила је Смиљана Стојановић у Зборнику Историјског музеја Србије, 1977, бр. 13-14, стр. 149-163 (извор, В. Јоксимовић 2015: 31).

${ }^{28}$ Малиша Станојевић је први обновио интерес за Милицу Јанковић, кроз свој магистарски рад „Теме и структура наративне прозе Милице Јанковић” (рукопис), одбрањен 1971. године на Филолошком факултету у Београду, под меторством проф. Милоша И. Бандића. 
делу Милице Јанковић предуго остао понављани и преписивани Скерлићев суд концетрисан само на њену прву збирку приповедака (Исповести, 1913 - остале као да нису ни постојале), без иоле обзиљнијег покушаја да се опус ове књижевнице темељно истражи и објективно одреди њено место у историји српске књижевности и књижевном канону.

\section{ЛИТЕРАТУРА}

Агапова 1938: М. Илић Агапова, Случај Милице Јанковић или Победа духа над материјом, Београдске општинске новине, Београд, бр. 4, стр. 291-294.

Бараћ 2015: С. Бараћ, Феминистичка контрајавност. Жанр женског nортрета у српској периодици 1920-1941, Београд: Институт за књижевност и уметност.

Гароња Радованац 2015: С. Гароња Радованац, Милица Јанковић у светлу истраживања Малише Станојевића, Наслеђе, бр. 30, Крагујевац: Филолошко-уметнички факултет, 15-16. Нолит.

Деретић 1983: Ј. Деретић, Историја српске кьижевности, Београд:

Ђукић-Перишић 2012: Ž. Đukić-Perišić, Pisac i priča: stvaralačka biografija Ive Andrića, Novi Sad: Akademska knjiga.

Ђурић 2015: В. Ђурић, Калуђер из Русије - аутофикционални портрет Милице Јанковић, Нова реалност из сопствене собе, у: (зборник радова) Кьижевно стваралаштво Милице Јанковић, Велико Градиште: Библиотека „Вук Караџић”; Београд Филолошки факултет, 21-34.

Јанковић 1913 (1922): М. Јанковић, Исповести, Издање И. Ђ. Ђурђевића, Сарајево.

Јанковић 1919: М. Јанковић, Калуђер из Русије, Издање И.Ђ.Ђурђевића, Београд-Сарајево.

Јанковић 1919: М. Јанковић, Незнани јунаци, Издање С. Б. Цвијановића, Београд.

Јанковић 1920: М. Јанковић, Чекање: одломции из историје робовања и из историје јунаштва, И. Ђ. Ђурђевић, Београд-Сарајево.

Јанковић 1922: М. Јанковић, Смрт и живот, Београд: Издавачка књижарница Напредак.

Јанковић 1929: М. Јанковић, Плави доброћудни вали, Београд: Удружење наставница средњих стручних школа.

Видети више у мом раду: „Милица Јанковић у светлу истраживања Малише Станојевића”, Наслеђе, бр. 30, Филолошко-уметнички факултет, Крагујевац, стр. 15-16. 
Јанковић 1932: М. Јанковић, Путем, Београд: Издавачка књижарница Геце Кона.

Јанковић 1932: М. Јанковић, Међу зидовима, Београд: Штампарија Јадран.

Јанковић 1937 : М. Јанковић, Људи из скамије, Београд: СКЗ.

Јоксимовић 2014: В. Јоксимовић, Стваралачка историја и приповедачки поступак Милице Јанковић у: Нова реалност из сопствене собе, (зборник радова) Књижевно стваралаштво Милице Јанковић, Велико Градиште-Београд, 21-34.

Калинић 2015: С. Калинић, „Нечисте жуди”, „минуле цвети” и „склопљени Верлен”: интимистички елементи поезије Данице Марковић, у: (зборник радова) Књиженство: теорија и историја женске књижевности на српском језику до 1915. године, Београд: Филолошки факултет, стр. 264.

Књиженство 2015: Кюиженство: теорија и историја женске књижевности на српском језику до 1915. године; (ур.) Биљана Дојчиновић, Александра Вранеш, Зорица Бечановић-Николић, Београд: Филолошки факултет Универзитета у Београду.

Маринковић 1977: Н. Маринковић, Мир и немир Исидоре Секулић, Книжевне новине, 16. фебруар 1977.

Нова реалност 2015: Нова реалност из сопствене собе, у: (зборник радова) Кюижевно стваралаштво Милице Јанковић, Велико Градиште: Библиотека „Вук Караџић”; Београд Филолошки факултет.

Скерлић 1967: Ј. Скерлић, Историја новије српске књижевности, (пр.) Мидхат Бегић, Сабрана дела, књ. XXXIII, Београд: Просвета.

Скерлић Ћоровић 2014: Ј. Скерлић Ћоровић, Живот међу људима: мемоарски записи, (пр.) Зорица Хаџић, Нови Сад: Академска књига.

Станојевић 1985: М. Станојевић, Живот и списатељска судбина Милице Јанковић, Анали Филолошког факултета 16, Београд, 181-193.

Стојановић 1977: С. Стојановић, Једна приповетка Милице Јанковић (Госпођа Анка Анђелковић), у: Зборник Историјског музеја Србије, бр. 13-14, стр. 149-163.

Тропин 2014: Т. Тропин, Милица Јанковић и књижевност за децу, Нова реалност из сопствене собе, у: (зборник радова) Книжевно стваралаштво Милице Јанковић, Велико Градиште: Библиотека „Вук Караџић”; Београд: Филолошки факултет, 21-34.

Ћосић 201: Б. Ћосић, Десет писаиа десет разговора, (пр.) Ј. Пејчић, Београд: Службени гласник. 
Удовички 1967: И. Удовички, Необјављени текст Бранимира Ћосића о Милици Јанковић, Прилози за књижевност, језик, историју и фолклор, књ. 33, св. 1-2, 121-127.

Slavica O. Garonja Radovanac

\section{MILICA JANKOVIĆ'S SHORT STORIES - A POSSIBLE AUTOBIOGRAPHY}

\section{Summary}

Although Milica Jankovic through hers narrative collections always wrote out "a book," qualitatively without changing (except in the penultimate collection Among the walls) - various discourses and thematic diversity talking about her exceptional qualities as a storyteller, but also disadvantages, which is harmed or postpone its timely reception in the history of Serbian literature. The artistic highlight of her short stories make up stories on the autobiographical background, as well as stories thematically unified around Belgrade's life before the Great War, war stories, as well as the Adriatic and Paris themes. Qualitative advances are short stories that have given the position of the narrator in the male gender (war stories - among them many anthological quality), while a special range of modernist lyric hyphens are among the Jews, and in this way, short story Milica Jankovic became much more interesting for research in the gender discourse .

Key words: Milica Jankovic, interwar collection, systematization of themes and motifs, gender aspect, autobiographical discourse. 